\title{
Quantification of the radiative and convective heat transfer processes and their effect on mSOFC by CFD modelling
}

\author{
Paulina Pianko-Oprych", Ekaterina Kasilova, Zdzisław Jaworski \\ West Pomeranian University of Technology, Szczecin, Institute of Chemical Engineering and Environmental Protection \\ Processes, al. Piastów 42, 71-065 Szczecin, Poland, \\ "Corresponding authors: e-mail: paulina.pianko@zut.edu.pl
}

\begin{abstract}
The CFD modelling of heat transfer in a microtubular Solid Oxide Fuel Cell (mSOFC) stack has been presented. Stack performance predictions were based on a 16 anode-supported microtubular SOFCs sub-stack, which is a component of the overall stack containing 64 fuel cells. Both radiative and convective heat transfer were taken into account in the modelling. The heat flux value corresponded to the cell voltage of 0.7 [V]. Two different cases of the inlet air velocity of 2.0 and $8.5\left[\mathrm{~ms}^{-1}\right]$ were considered. It was found that radiation accounted for about 20-30 [\%] of the total heat flux from the active tube surface, which means that the convective heat transfer predominated over the radiative one.
\end{abstract}

Keywords: microtubular Solid Oxide Fuel Cell stack, heat transfer, Computational Fluid Dynamics, temperature distributions.

\section{INTRODUCTION}

Knowledge of heat transfer characteristics and thermal management are important issues in the development of microtubular Solid Oxide Fuel Cell stacks (mSOFC) due to the temperature dependence of mSOFC properties. Too high temperatures degrade the materials, while too low temperatures impair the power output. Large temperature gradients are detrimental to the stack and may cause its damage and crack. In order to avoid damage to the mSOFC stack the temperature distribution in the stack should be as uniform as possible to minimize the internal thermal gradients. Therefore, a fundamental understanding of heat transfer through the mSOFC stack is required.

Useful tools in the thermal management of the mSOFC stack assessment are numerical codes of Computational Fluid Dynamics (CFD). The earliest CFD modelling of microtubular Solid Oxide Fuel Cell stack was reported by Lockett et al. ${ }^{1}$. The main aim of this CFD research was characterization of heat transfer in microtubular cells and stack. This allowed to identify the stack design and operating conditions that led to the optimal performance and efficient thermal management. The mSOFC stack contained 20 fuel cells with power output in the region of $0.4-0.6$ [W] per cell. A structured mesh was generated for the stack geometry. Hydrogen was the fuel flowing inside the microtubular fuel cells with the mass flow rates corresponding to an average value of 20 [slm] per tube ${ }^{\mathbf{1}}$. The inlet air temperature in the CFD model was assumed $1123[\mathrm{~K}]$ fuel cell temperature in experiments. With air in the countercurrent flow to the fuel the optimum air temperature was found close to $673[\mathrm{~K}]^{1}$.

A 2D axisymmetric, numerical model of a microtubular single chamber Solid Oxide Fuel Cell using the commercial COMSOL Multiphysics 4.3 CFD software was presented by Akhtar et al. ${ }^{2}$. The model took into account the methane full combustion, steam reforming, dry reforming and water gas shift reaction followed by electrochemical oxidation of the produced hydrogen within the anode zone. An average temperature of 1023 $[\mathrm{K}]$ was assumed for the single chamber Solid Oxide Fuel Cell. The temperature of the anode surface along the fuel cell length decreased up to the complete cathode length and then increased along the remaining cell length. The temperature growth was explained by to the presence of anode current collectors which generated additional resistive heat.

Akhtar ${ }^{3}$ expanded the CFD model used in the previous work $^{2}$. The temperature at the fuel cell inlet was higher and decreased along the fuel cell length. It was explained by the leading exothermic combustion reaction directly at the fuel cell entrance. Subsequent reforming reactions down the fuel cell length were endothermic. For the case of the bare gas chamber the temperature dropped down between the first fuel cell and the third one along the gas chamber length. However, in the second considered case with a porous insert a slightly increasing trend in fuel cell temperature was observed, starting from the first to the third fuel cell down the gas chamber length. Yet the maximum temperature in this case was lower than for the bare gas chamber case. It was explained by better heat convection from the fuel cell surface to the porous material ${ }^{3}$. The author ${ }^{3}$ noticed that adding a material of higher thermal conductivity acted as a thermal fin and took heat away from the fuel cells, transported it to the surrounding gas mixture. It was concluded that the proposed solution with the porous material helped in lowering thermal stresses induced in the fuel cell.

A numerical study of the anode-supported microtubular SOFC stack with six single fuel cells was performed by Lee et $a l .{ }^{4}$. In this study, the CFD model included sets of equations for momentum, energy and the species transport, which were applied to the stack domain and solved giving local profiles of temperature, electric current density and concentrations. Simulations using the model were run at the flow rates of fuel (hydrogen) and air of 15 and 40 [slm], respectively. The mSOFC stack showed a maximum power of approximately $700[\mathrm{~W}]$ at $1023[\mathrm{~K}]$ and at fuel utilization of 49 [\%]. The mSOFC stack achieved a high power density of $0.38\left[\mathrm{Wcm}^{-2}\right]$.

Numerical investigations ${ }^{1-4}$ have developed 2D and 3D models for calculation of the thermal performance characteristics of the microtubular Solid Oxide Fuel Cell stacks, but it follows from the literature review that the 
influence of radiation and convection heat transfer processes in the microtubular SOFC stacks have received much less attention in comparison to numerous numerical studies carried out for planar SOFC stacks ${ }^{5}$. Therefore, the main purpose of the paper was to work out a numerical modelling method leading to quantification of the radiative and convective heat transfer processes and their effects on a microtubular Solid Oxide Fuel Cell stack.

\section{The method of modelling}

The method of Computational Fluid Dynamics (CFD) was applied to simulate heat transfer in a microtubular Solid Oxide Fuel Cell stack containing 64 fuel cells. In the simulations the microtubular cells with supporting anode were adopted. The outer diameter of the fuel cell tubes was 6.7 [mm], while the active length of fuel cells was equaled to 100.5 [mm] (Fig. 1).

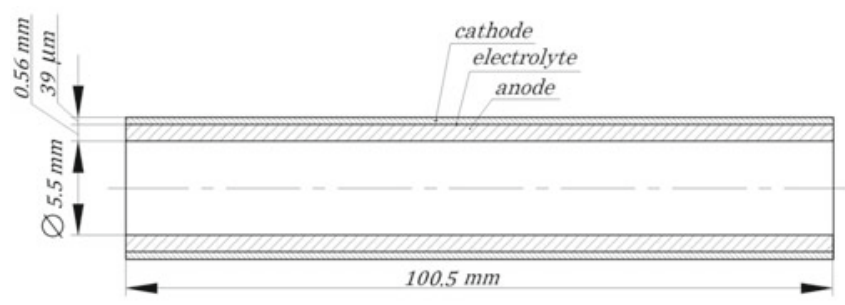

Figure 1. Geometry of the single microtubular SOFC

According to CFD results of the micro-tubular SOFC $^{6,7}$, the fuel took off only 5-10 [\%] of the heat released parallel to electrochemical reactions. Therefore it was concluded that the fuel cells were cooled mainly by the cathode air flow. Based on that conclusion it was assumed that the heat management in the stack modelling was defined by heat transfer between the cell and air flowing in the stack. Therefore, a simple CFD model of the mSOFC stack was established to obtain temperature distributions in the stack and to estimate temperature gradients. A constant heat flux value was set for the electrochemically active part of the fuel cell tubes. The heat flux value was calculated using an analytical estimation based on experimental U-I curves ${ }^{\mathbf{8}}$. In this approach the heat flux value, q, was estimated from equation (1):

$\mathrm{q}=\frac{1-\eta}{\eta} \cdot \mathrm{W}_{\mathrm{el}}$

where the mSOFC efficiency, $\eta$, of 30 [\%] was assumed. The mSOFC efficiency corresponds to the constant voltage of $0.7[\mathrm{~V}]$ and the electrical power, $\mathrm{W}_{\mathrm{el}}$, of 0.3 [W cm$\left.{ }^{-2}\right]$ according to the literature data'. With those figures, the heat flux value should be approximately 0.7 $\left[\mathrm{W} \mathrm{cm}{ }^{-2}\right]$. Therefore, the heat flux was assumed higher, at $0.75\left[\mathrm{~W} \mathrm{~cm}^{-2}\right]$ for the active fuel cells part in the mSOFC stack simulations.

To develop a simplified low order mSOFC stack model the following additional assumptions were made: the computational domain (cathode side) consisted only of the air volume, therefore both the fuel channel and the membrane-electrode assembly (MEA) were not included in the calculations.

In the presented CFD model the coupling of heat transfer with electrochemistry and charge transfer was neglected, while radiative and convective heat trans- fer were taken into account. Inlets and outlets of the mSOFC stack were assumed to be participating surfaces for radiative heat transfer with an emissivity of 1.0. The CFD model was based on the standard Navier - Stokes equations (Eq. (2), (3)) along with the energy transport equation (Eq. (4)), which were numerically solved in the laminar flow regime and for the steady - state conditions:

$\nabla \cdot(\rho \bar{u})=0$

$\nabla \cdot(\rho \overline{\mathrm{uu}})=\nabla\left(\mu\left[\left(\nabla \overline{\mathrm{u}}+\nabla \overline{\mathrm{u}}^{\mathrm{T}}\right)-\frac{2}{3} \nabla \overline{\mathrm{u}} \overline{\mathrm{I}}\right]\right)+\rho \overline{\mathrm{g}}-\nabla \mathrm{p}$

$\nabla \cdot\left(\rho \mathrm{c}_{\mathrm{p}} \overline{\mathrm{u}} \overline{\mathrm{T}}\right)=\nabla \cdot(\lambda \nabla \overline{\mathrm{T}})$

where: $\mathrm{Q}$ - density, $\overline{\mathrm{u}}$ - velocity, $\mathrm{p}$ - pressure, $\mu$ - kinematic viscosity, $\lambda-$ heat conductivity, $\mathrm{T}-$ temperature. The terms on the left hand side of Eqs. (3) and (4) represent the rates of addition by convection of momentum and energy, respectively. The first term on the right hand side of these equations describes the contribution of the molecular transport. Numerical solutions of these equations allow to predict the local velocities and temperatures.

The commercial CFD code ANSYS Fluent 14.0 was used in the heat transfer simulations for the mSOFC stack. The Gambit 2.0 pre-processor was employed to create a 3D geometry of the quarter of the mSOFC stack to take advantage of the stack symmetry and to build a numerical grid with 89088 computational cells. The quality of the grid was examined by the EquiAngleSkew parameter as well as other grid parameters. The minimum orthogonal quality was 0.88 , while the maximum aspect ratio was equal to 2.5 . The geometry of the quarter of the mSOFC stack is shown in Figure 2.

All the boundary conditions for heat transfer were defined in the ANSYS code. The air temperature at the inlet was assumed at 973 [K] and two levels of the cathode air velocity of 2.0 and $8.5\left[\mathrm{~m} \mathrm{~s}^{-1}\right]$ were chosen. The outlet surface was set as pressure outlet. The stack walls were defined as stationary walls with zero heat losses, i.e. the walls were assumed adiabatic. The active part of the fuel cell tubes was defined as stationary wall with 0.75 [W cm $\mathrm{cm}^{-2}$ heat flux and emissivity of 0.4 . The inert part of the fuel cell tubes was also assumed adiabatic. Natural convection was found negligible, while the radiative heat transfer was quite important for the mSOFC cooling. The impact of the radiative heat transfer was estimated close to 20-30 [\%] of the mSOFC heat flux using the standard surface - to - surface model. The cathode air was a non-participating media in radiation. The gas properties based on the ANSYS database were used in the simulations and air was treated as the ideal gas.

The calculations were performed with the default numerical parameters available in the code to achieve a low level of the normalized residual sum of $10^{-13}-10^{-17}$ for the energy equation (4). The converged simulations provided the local values of the velocity, pressure and temperature.

\section{RESULTS AND DISCUSSION}

In the first stage of the modelling, the numerical procedure for analyzing the heat transfer in the microtubular Solid Oxide Fuel Cell stack was checked by comparing the simulated values of pressure drop for the two considered 


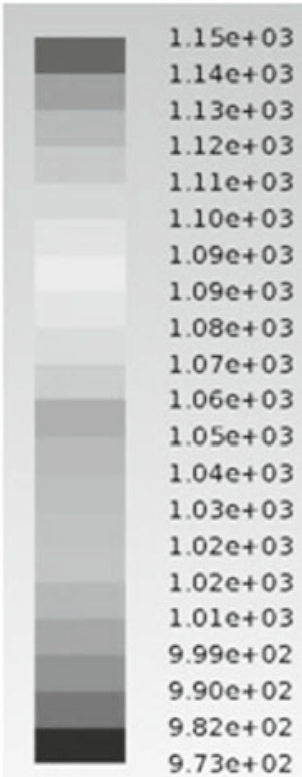

a)

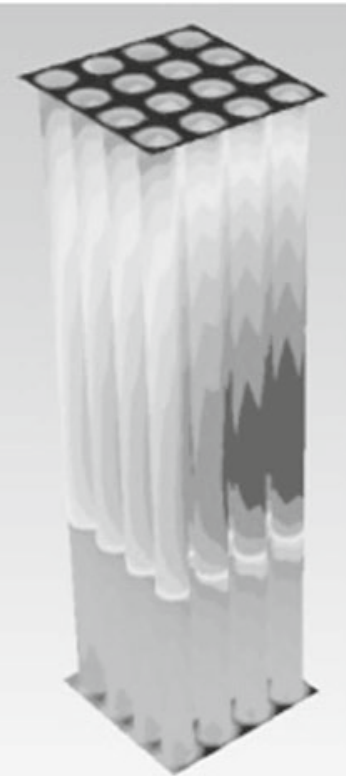

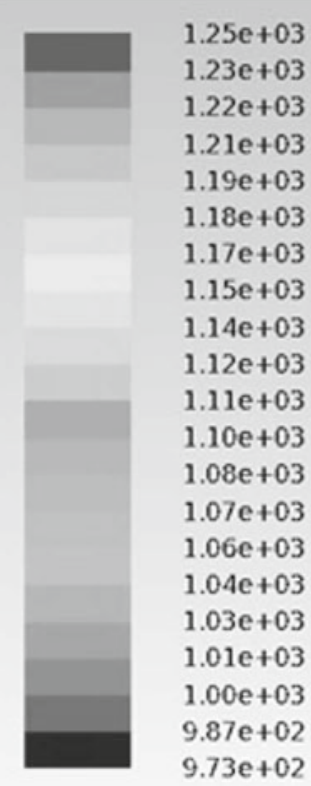

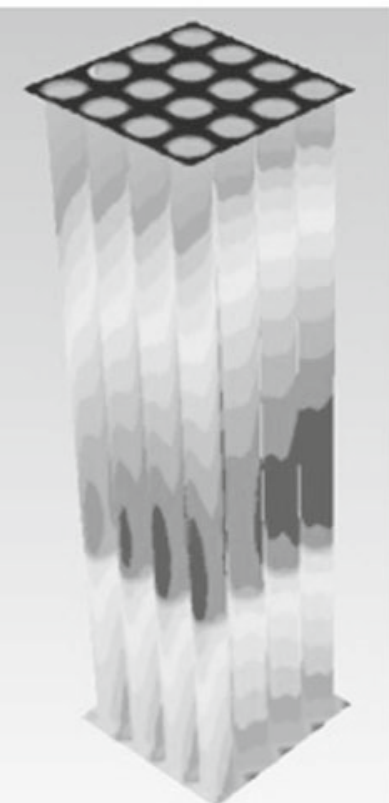

b)

Figure 2. Temperature of the fuel cell tubes at the air inlet velocities: (a) $8.5\left[\mathrm{~m} \mathrm{~s}^{-1}\right]$, (b) $2.0\left[\mathrm{~m} \mathrm{~s}^{-1}\right]$

cases (at the inlet air velocity of 2.0 and $8.5\left[\mathrm{~m} \mathrm{~s}^{-1}\right]$ ), with the corresponding theoretical values for straight tubes ${ }^{\mathbf{1 0}}$. The computed pressure loss during the flow in the mSOFC stack was about 3.8 and $19.6[\mathrm{~Pa}$ ] for the inlet air velocity of 2.0 and $8.5\left[\mathrm{~m} \mathrm{~s}^{-1}\right]$, respectively and differed from the theoretical ones ${ }^{\mathbf{1 0}}$ by less than $11 \%$.

A graphical presentation of the simulated distribution of the local temperature within the mSOFC stack is shown in Figures 2-4. It was observed that the temperature differences along the fuel cells were up to 110 $[\mathrm{K}]$ and $15[\mathrm{~K}]$ for the inlet air velocity of 2.0 and 8.5 $\left[\mathrm{m} \mathrm{s}^{-1}\right]$, respectively.

The simulation results shown in Figure 3 revealed that the temperature distributions along the stack enclosure varied quite sharply at the border between the active and the inert parts of the tubes. Such a behavior can partly be explained by the fact that the heat conductivity of the solid tubes was not taken into account in the CFD model. It should also be noted that the conductivity of SOFC materials are strongly related to temperature as well as other relevant factors discussed in detail by Kupecki et al. ${ }^{11}$ It is expected that the temperature profiles will be smoother when full numerical approach is applied.

Another analyzed quantity was the maximal temperature difference between the middle fuel cell tube and the corner. The tube circumference averaged values of the temperature along the middle and corner fuel cells obtained from the CFD solutions in the mSOFC stack are shown in Figures 4 for comparison. The shape of the temperature distribution curves for the air flow velocity of 2.0 and $8.5\left[\mathrm{~m} \mathrm{~s}^{-1}\right]$ along a corner and middle fuel cell tubes were generally similar. However higher temperature rises were observed at the lower value of the air flow velocity.

It follows from the plots (Figure 4) that the maximal temperature difference between the middle fuel cell tube and the corner one was about $323[\mathrm{~K}]$ at the two considered air velocity values.

It also follows from the CFD results that the present approach is an effective and relatively easy way to predict heat transfer in the microtubular Solid Oxide Fuel Cell stack. In particular, further extension of the CFD model by coupling flow and heat transfer with electrochemistry

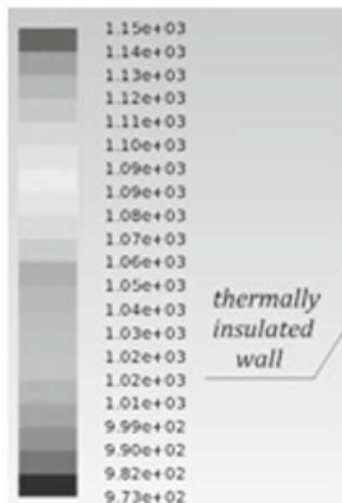

a)

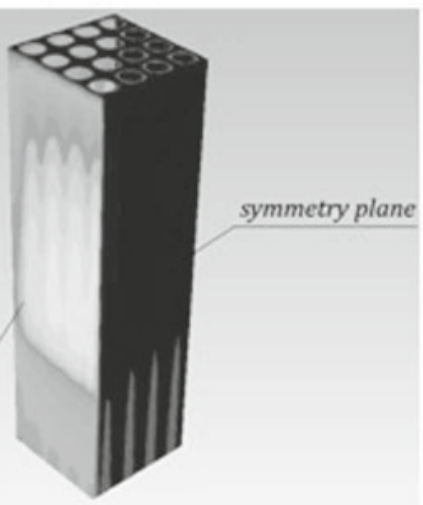

b)

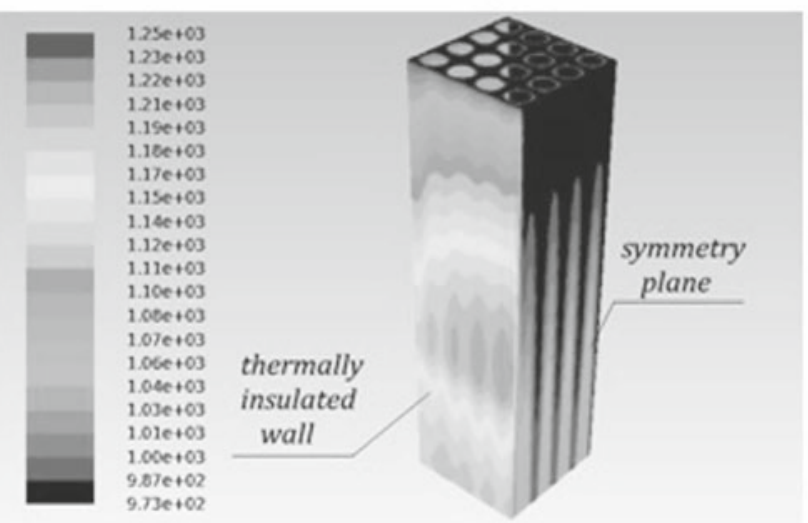

b)

Figure 3. Temperature distributions on the mSOFC stack walls and symmetry planes at the air inlet velocities: (a) 8.5 [m s $\mathrm{m}^{-1}$ ], (b) 2.0 $\left[\mathrm{m} \mathrm{s}^{-1}\right]$ 


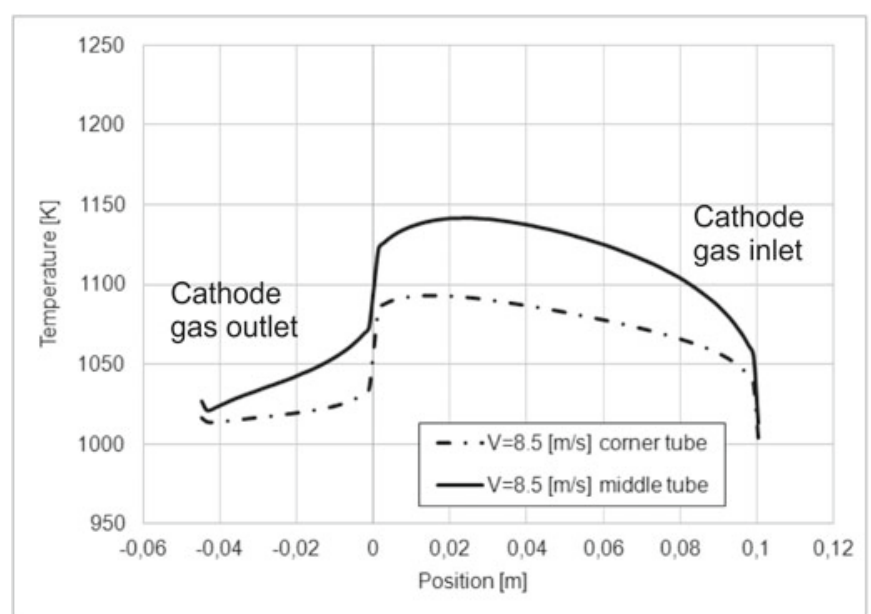

(a)

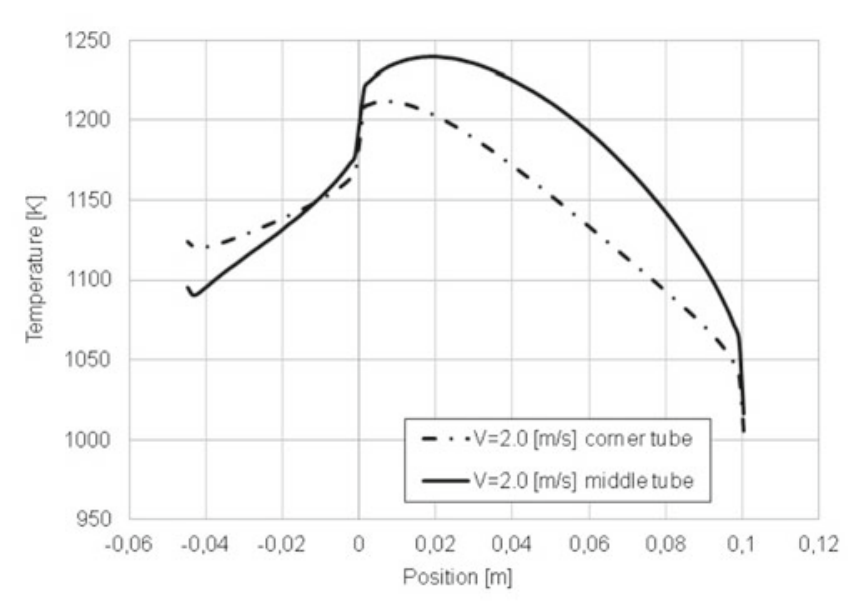

(b)

Figure 4. Temperature distributions along the corner and middle fuel cell tubes at the air flow velocities of: (a) 8.5 [m $\mathrm{s}^{-1}$ ] and (b) $2.0\left[\mathrm{~m} \mathrm{~s}^{-1}\right]$

can be considered as an efficient and useful tool for designing and optimizing the microtubular SOFC stack.

\section{CONCLUSIONS}

To investigate heat transfer, a 3D model has been developed for calculation of the thermal performance characteristics of the microtubular Solid Oxide Fuel Cell stack for two values of the cathode air velocity of 2.0 and $8.5\left[\mathrm{~m} \mathrm{~s}^{-1}\right]$. The results of the simulations led to the following conclusions:

- radiation took off about 20-30 [\%] of the overall heat from the active tube surface, which means that the convective heat transfer predominated over the radiative one,

- it was found that the area with the maximal temperature gradient values was at the boundary between the active part of the fuel cell tube and the inert one,

- the maximum temperature in the mSOFC stack was $1250[\mathrm{~K}]$ at $2.0\left[\mathrm{~m} \mathrm{~s}^{-1}\right]$ and $1150[\mathrm{~K}]$ at $8.5\left[\mathrm{~m} \mathrm{~s}^{-1}\right]$, respectively,

- the maximal difference between the temperature of the middle fuel cell tube and the temperature of the peripheral one was about $323[\mathrm{~K}]$ at the two air velocities studied.

Numerical approach and CFD results presented in the paper allowed to estimate the radiative and convective heat transfer processes and their effects on a microtubular Solid Oxide Fuel Cell stack.

\section{NOMENCLATURE}

$\mathrm{c}_{\mathrm{p}} \quad-$ average specific heat, $\left[\mathrm{Jkg}^{-1} \mathrm{~K}^{-1}\right]$

$\bar{g} \quad-$ acceleration due to gravity, $\left[\mathrm{m} \mathrm{s}^{-2}\right]$

$\mathrm{p} \quad-$ pressure, $[\mathrm{Pa}]$

$\mathrm{T} \quad$ - temperature, $[\mathrm{K}]$

$\overline{\mathrm{u}} \quad-$ velocity, $\left[\mathrm{m} \mathrm{s}^{-1}\right]$

$\mathrm{W}_{\mathrm{el}} \quad-$ electric power, $\left[\mathrm{W} \mathrm{cm} \mathrm{cm}^{-2}\right]$

$\mathrm{q} \quad-$ heat flux, [W $\mathrm{cm}^{-2}$ ]

\section{Greek symbols}

$\lambda \quad$ - heat conductivity, [W $\mathrm{m}^{-1} \mathrm{~K}^{-1}$ ]

$\mu \quad-$ kinematic viscosity, [Pas]

Q $\quad-$ density, $\left[\mathrm{kg} \mathrm{m}^{-3}\right]$

$\eta \quad-$ efficiency, [\%]

\section{ACKNOWLEDGMENT}

The research programme leading to these results received funding from the European Union's Seventh Framework Programme (FP7/2007-2013) for the Fuel Cells and Hydrogen Joint Technology Initiative under grant agreement no [278629]. Information contained in the paper reflects only view of the authors. The FCH $\mathrm{JU}$ and the Union are not liable for any use that may be made of the information contained therein. Acknowledgments are due to the partners of SUAV: E. de Wit, M. Walter, J.P. Brouwer of HyGear Fuel Cell Systems B.V., The Netherlands; M. Kendall, K. Kendall of Adelan Ltd., UK; T. Hargitai, F. Silversand, A.K. Jannasch, M. Lenberg, Ch. Karlsson of Catator AB, Sweden; V. Antonucci, A.S. Arico, M. Ferraro of Consiglio Nazionale delle Ricerche, Italy; G. Schramm, M. Yadira, NarvaezClemente of EADS Deutschland GmbH, Germany; J. Price, T. Owen, M. Maynard of EADS UK Ltd.; E. Erdle of efceco, Germany; R. Steinberger - Wilckens, A. Dhir, B. Hari, T. Meadowcroft of The University of Birmingham, UK; P. Tantot, E. Georges, J. Chapuis, J. M. Masenelli of Survey Copter, France.

The work was also financed from the Polish research funds awarded for the project No. W20317.PR/2011 of international cooperation within SUAV in years 2011-2014.

\section{LITERATURE CITED}

1. Lockett, M., Simmons, M.J.H. \& Kendall, K. (2004). CFD to predict temperature profiles for scale up of microtubular SOFC stacks. J. Pow. Sources. 131, 243-246. DOI: 10.1016/j.powsour.2003.11.082.

2. Akhtar, N., Decent, S.P. \& Kendall, K. (2010). Numerical modelling of methane-powered microtubular single chamber solid oxide fuel cell. J. Pow. Sources. 195, 7796-7807. DOI: 10.1016/j.powesourc.2010.01.084.

3. Akhtar, N. (2012). Microtubular, single-chamber solid oxide fuel cell (MT-SC-SOFC) stacks: Model development. Chem. Eng. Res. \& Des. 90, 814-824. DOI: 10.1016/j.cherd.2011/09/013.

4. Lee, S.B., Lim, T.H., Song, R.H., Shin, D.R. \& Dong, S.K. (2008). Development of a $700 \mathrm{~W}$ anode-supported micro-tubular SOFC stack for APU applications. Inter. 
J. Hydrogen Energy. 33, 2330-2336. DOI: 10.1016/j.ijhydene.2008.02.034.

5. Zeng, M., Yuan, J., Zhang, J., Sunden, B. \& Wang, Q. (2012). Investigation of thermal radiation effects on solid oxide fuel cell performance by a comprehensive model. J. Pow. Sources. 206, 185-296. DOI: 10.1016/j. powsour.2012.01.130.

6. Andersson, M., Yuan, J. \& Sunden, B. (2012). SOFC modeling considering electrochemical reactions at the active three phase boundaries. Inter. J. Heat \& Mass Transfer. 55, 773-788. DOI: 10.1016/j.ijheatmasstransfer.2011.10.032.

7. Meier, Ch., Hocker, Th. Bieberle-Hutter, A. \& Gauckler, L. (2012). Analyzing a micro-solid oxide fuel cell system by global energy balances. Inter. J. Hydrogen Energy. 37, 10318-10327. DOI: 10.1016/j.ijhydene.2012.04.009.

8. Pianko-Oprych, P., Kasilova, E. \& Jaworski, Z. (2013). Modelling of processes in a microtubular Solid Oxide Fuel Cell. Inż. Apar. Chem. 5, 462-464.

9. Howe, K., Thompson, G.J. \& Kendal, K. (2011). Micro-tubular solid oxide fuel cells and stacks. $J$. Pow. Sources, 196, 1677-1686. DOI: 10.1016/j.jpowsour.2010.09.043.

10. Meadowcroft, A.D., Kendall, K., Kendall, M. (2013). Internal report on testing micro-tubular SOFCs in Unmanned Air Vehicles, SUAV project.

11. Kupecki, J., Milewski, J. Jewulski, J. (2013). Investigation of SOFC material properties for plant-level modelling. Centr. Europ. J. Chem., 11, 5, 664-671. 